\title{
Digital games (Gamification) in Learning and Training: An Approach to Adaptation and Integration in the Classroom ${ }^{1}$
}

Juegos Digitales (Gamificación) en el Aprendizaje y la Formación: Un Acercamiento a la Adaptación e Integración en el Aula

\section{Zulma Liliana Vargas-Macías, Ariel Adolfo Rodríguez-Hernandez and Claudia Liliana Sánchez-Sáenz ${ }^{2 *}$}

Universidad Pedagógica y Tecnológica de Colombia, Colombia

1 Received: February $26^{\text {th }}$ 2019/Accepted: May $18^{\text {th }} 2020$

2 zulmaliliana.vargas1@uptc.edu.co; ariel.rodriguez@uptc.edu.co; claudialiliana.sanchez1@uptc.edu.co 


\section{Abstract}

This article is the result of the SGI 2174 project. Its objective is to identify how elements, techniques and mechanics game (gamification) have been implemented, as an ICT-mediated learning strategy for learning and training in the education. A systemic literary review of works on the subject is carried out to contextualize and identify methods, techniques, tools and platforms of gamification. The results make an analysis of the articles reviewed, and describe and describe the technologies and methodologies of gamification and the most relevant results with which gamification has been implemented in educational and business environments. This project is developed in the research groups TelemaTICs and TICA, and funded by DIN-UPTC.

Keywords: learning and technology; education and ICT; e-learning, gamification; adaptation; integration; classroom, business environments

\section{Resumen}

Este artículo es el resultado del proyecto SGI 2174. Su objetivo es identificar cómo se han implementado los elementos, las técnicas y el juego de mecánica (gamificación), como una estrategia de aprendizaje mediada por las TIC para el aprendizaje en la educación y la formación. Se realizo una revisión literaria sistémica de trabajos sobre el tema para contextualizar e identificar métodos, técnicas, herramientas y plataformas de gamificación. Los resultados hacen un análisis de los artículos revisados y describen las tecnologías y metodogias de gamificación y los resultados de mayor relevancia con la que se ha implementado la gamificación en entornos educativos y empresariales. Este proyecto se desarrolla en los grupos de investigación TelemaTICs y TICA, y está financiado por DIN-UPTC.

Palabras clave: aprendizaje y tecnología, educación y TIC; aprendizaje virtual; gamificación; adaptación; integración; aula; ambientes de negocios

\section{Resumo}

Este trabalho surge do seguinte problema: como implementar elementos, técnicas e mecânicas de jogo (gamificação) a maneira de estratégias de aprendizagem mediadas pelas TIC para a aprendizagem e a formação na educação do século XXI? Neste artigo, ao mesmo tempo, descrevese o crescimento desta tecnologia, usada em entornos educativos e empresariais. Também se faz uma revisão sistemática dos trabalhos sobre o tema para contextualizar e identificar métodos, técnicas, ferramentas e plataformas de gamificação. O projeto atualmente é desenvolvido nos grupos de pesquisa TelemaTICs e TICA, e está financiado pelo Código de Projeto DIN SGI 2174.

Palavras chave: aprendizagem e tecnologia; educação e TIC; aprendizagem virtual; gamificação; adaptação, integração; sala de aula; ambientes de negócios. 


\section{Introduction}

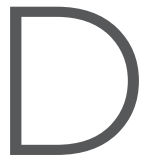

uring the last decade, games have become a fundamental task within the learning process by students (Hamari \& Keronen, 2017), the use and implementation of technological tools day by day converge more to an education mediated by information technologies and communication (ICT), the educational methodologies usually used each time require a high degree of innovation (Galbis-Córdova, Martí-Parreño, \& Curras-Perez, 2017) in order to implement improvements in educational originality and not replace them completely and thus generate an environment of innovation within of the academic scenario (Hamari, Koivisto, \& Sarsa, 2014).

The technological advances of the hand of the learning give rise to the calls "digital challenges" (Roosta, Taghiyareh, \& Mosharraf, 2016), as well as a hybrid between learning-games based on learning-gamification. The games every day become a different way of attracting the attention of the students. In the research of Hanus and Fox (2015) they are defined as the largest information system of leisure in the last decade, resulting in enjoyment and utility that the user gives to the game, considering determining factors for its success.

However, when implementing game elements especially in e-learning platforms, it is required as recommended for Bonillaware (2012) to have experts in technology, pedagogy and design, in order to optimize the development processes of the analysis and design phases of the elements of the game. In Colombia, it was not possible to identify duly documented experiences of the use of gamification in educational settings.

\section{Resources and Methods}

Within the literature review to carry out this exploratory research, initially we proceeded to investigate the databases repository that had similarity to the study area that was intended to be evaluated, in this case gamification. Resulting in the following list of repositories and databases: Scopus, ACM, IEEE, Google Scholar, Science Direct and Digitalia, as a second instance, a search by keyword (Gamification, Gamification in education) was carried out, resulting in a number of searches of approximately 23,712 articles. As the volume of works identified was high, a time range was defined that consisted of searching for articles published between 2010 and 2018, reaching 8,400 papers. The result of this exploration is presented in Table 1 . 
Table 1. Related articles according to search criteria.

\begin{tabular}{|c|c|c|c|c|}
\hline Item & Database & Keyword & $\begin{array}{c}\text { Result } \\
\text { global }\end{array}$ & $\begin{array}{c}\text { Result apply- } \\
\text { ing time range }\end{array}$ \\
\hline 1 & Scopus & $\begin{array}{c}\text { Gamification in } \\
\text { education }\end{array}$ & 846 & 191 \\
\hline 2 & ACM & Gamification & 487 & 489 \\
\hline 3 & IEEE & Gamification & 518 & 36 \\
\hline 4 & Google Scholar & $\begin{array}{c}\text { Gamification in } \\
\text { education }\end{array}$ & 21.000 & 7.400 \\
\hline 5 & Science Direct & Gamification & 831 & 262 \\
\hline 6 & Digitalia & Gamification & 30 & 22 \\
\hline
\end{tabular}

To get a more explicit analysis of the papers found, we proceeded to filter by explicit areas of gamification implementation. Taking as a variable the study population, and the study area; and thus make a review through RAE cards that characterize each study in a more relevant way. 38 articles were reached, which were identified in the different application areas in which gamification is implemented, see Table 2.

Table 2. Classification of areas in which gamification was implemented in the selected studies.

\begin{tabular}{|c|c|c|}
\hline Item & Área & Total articles reviewed \\
\hline 1 & Gamification applied to education & 17 \\
\hline 2 & Gamification applied to the internet of things & 3 \\
\hline 3 & Gamification applied to the tourism sector & 2 \\
\hline 4 & Gamification applied in cultural programs & 7 \\
\hline 5 & Gamification applied as a research area & 4 \\
\hline 6 & Gamification applied to social networks & 1 \\
\hline 7 & Gamification applying in augmented reality & 1 \\
\hline 8 & Gamification applied to the business sector & \\
\hline
\end{tabular}

\section{Literature Analysis and Results}

The was systematic documentary review process. Seano (2016) recommends "knowing the main documentary sources, as well as mastering the mechanisms of access, search, collection, and organization of such documentation". 
For this work, a characterization of the literature was made, which consisted of organizing and categorizing the articles that were found, for which a search equation was created. Which allowed to structure the searches and segregate the articles by focus and within the time window. A large amount of data was collected; which made it necessary to identify each work with a RAE (Analytical Summary of Writing) tab.

Through this RAE, through this, the description of each work was carried out, identifying relevant factors such as tools and development platforms. Below are the results obtained in this literary review.

The results obtained in the study of Benito (2014) express that it is fundamental to emphasize the learning style of each user, since not all individuals possess the same personality traits when receiving new knowledge; the research proposes a model for the realization of the learning style, starting as the first instance of the identification of perception, then the commitment that the individual acquires with respect to the new knowledge, and finally determining the performance of the new learning, it is concluded that the users that they have active learning styles (It is a method that engages students in the material they are learning through problem solving activities, writing assignments, group discussion, reflection, games, and other activities that promote critical thinking) have a result of implementation of positive gamification, while people with extrovert personality traits adapt more easily to traditional learning methods (is a method that focuses on the teacher and his ability to share education, leaving the student as a passive actor, making the student to listen as a primary action but they are interaction between him, his classmates or the resources).

For the research developed by Roosta, Taghiyareh, and Mosharraf (2016), it is important to categorize the elements of gamification according to the type of motivation derived from each user, as a result of the study that was implemented in an English course of the University of Tehran in Iran, concluded that the participation measures demonstrate the effectiveness of the personalization approach in the motivation of the students. Based on the findings, it is suggested to make an integrated categorization of the gamification elements without forgetting the motivation through personalization.

At University Midwest Hanus and Fox (2015) developed a course with a gamified resume for one group, in this they created a leaderboard and insignia, and another the group received the same curriculum but no gamification elements. As a result, the students enrolled in the gamified course showed more motivation, satisfaction and training than the students in the group that did not integrate games in class.

Students in the CM show less motivation and lower scores on the final exam than those in the non-gamified class (Hanus \& Fox, 2015). This suggests that special care must be taken when applying certain gamification mechanisms for educational environments, concluding that there is a knowledge gap in the understanding of 
the advantages and disadvantages of gamification, between the complexity of the implementation of a game feature and the impact that it has.

For the development of educational projects which require the integration of gamification models, as a learning strategy, it is advisable to include game dynamics in an educational environment. Bonillaware (2012) indicates that the use of game dynamics, mechanics and components allow for better interaction between students and teachers, gamification incorporates the use of design elements for games, but applied to contexts totally different from games.

In the integration of gamification to education (Seaone, 2016) indicates that it is essential to identify which is the appropriate platform for the implementation of this type of project. And you must define the activities and processes that will be taken into account within the dynamics of the game to develop for it to be successful.

The variety of digital applications found on the network allows the use of already developed components to adapt the mechanics and resources of gamification to any educational setting. Each project must be clear about the objective of using gamification, the platform to use and the activities so that gamification is integrated into education, marketing or research. The most used platforms and the recommended tools to start gamification projects, see Table 3 . 
Table 3. Description of platforms used in the studies consulted

\begin{tabular}{|l|l|}
\hline Plataform & Characteristics \\
\hline Badgeville & $\begin{array}{l}\text { This solution allows you to create games that have clear objectives and are } \\
\text { based on custom rewards. Badgeville is made up of: a widget generator, API, } \\
\text { a mobile SDK, connectors with Omniture, Yammer, among many more } \\
\text { solutions. } \\
\text { This web portal brings users a lot of gamification resources that can be used in } \\
\text { different business and corporate contexts. }\end{array}$ \\
\hline BigDoor & $\begin{array}{l}\text { Platform with 2 versions (a free one and a paid one) in which you can export } \\
\text { services to your website. It is integrated to social networks such as Facebook } \\
\text { or Twitter. }\end{array}$ \\
\hline Gigya & $\begin{array}{l}\text { It allows creating resources that can be integrated into corporate applications } \\
\text { through social networks. The platform has a large number of integrated } \\
\text { functions (e.g., REST APIs, as well as the use of servers with .NET, Java, PHP, } \\
\text { SDKs for iOS, Android, and Flash). }\end{array}$ \\
\hline Stopped.at & $\begin{array}{l}\text { The platform is linked to corporate websites and offers gamification services } \\
\text { to attract users of these websites. In addition, content can be shared on social } \\
\text { networks. }\end{array}$ \\
\hline Kiip & $\begin{array}{l}\text { It is a mobile advertising platform that uses gamification to create, in video } \\
\text { games, a system of rewards and apply it to the real world. }\end{array}$ \\
\hline Gamify & $\begin{array}{l}\text { This platform allows you to create games that have personalized rewards. It } \\
\text { has a kit consisting of: a widget generator, an API, a mobile SDK, connectors } \\
\text { with Omniture, Yammer and many more applications. }\end{array}$ \\
\hline
\end{tabular}

Note. Adapted from "7 plataformas de gamificación [7 gamification platforms]," by Bonillaware, 2012 (http://www.bonillaware.com/7-plataformas-de-gamificacion).

From the tools identified in the research referred to in this article, it was evidenced that among those most used for education, those described in table 4 stand out. 
Table 4. Description of Tools and Characteristics Used in the Studies Consulted

\begin{tabular}{|l|l|}
\hline \multicolumn{1}{|c|}{ Tools } & \multicolumn{1}{c|}{ Characteristics } \\
\hline Arcademics & $\begin{array}{l}\text { Web application to create interactive multiplayer games for learning pur- } \\
\text { poses. With multiplayer features. } \\
\text { Web application to create game-based activities, with a reward system and } \\
\text { achievement-oriented. }\end{array}$ \\
\hline Classdojo & $\begin{array}{l}\text { It is a platform based on a reward system, and the evaluation of attitudes, } \\
\text { behaviors through roles defined by the creator of the activity designed in } \\
\text { the form of a game. }\end{array}$ \\
\hline Playbuzz & $\begin{array}{l}\text { A publishing platform to create questionnaires, games, surveys, lists, etc. } \\
\text { This content can be shared online. }\end{array}$ \\
\hline EducaPlay & In this platform you can create and share learning activities online. \\
\hline Zondle & This website allows you to create educational video games. \\
\hline Kubbu & Provides a variety of interactive and didactic exercises. \\
\hline ProProfs & $\begin{array}{l}\text { System to create online learning activities, using surveys, evaluations and } \\
\text { contests in the form of games. }\end{array}$ \\
\hline Quimitris & $\begin{array}{l}\text { Web application that creates a game based on classic Tetris to learn the } \\
\text { chemical elements and their properties on the periodic table. }\end{array}$ \\
\hline
\end{tabular}

Nowadays, there is a diversity of countries around the world that use gamification as an alternative for solving problems at the business level, among which you can have: training of personnel at work or educational level, development of evaluations and workshops, needs studies, launch of new products or services, and customer loyalty (Benito, 2014). The gamification can help companies and educational institutions to experiment and seek solutions to training, teaching-learning problems, among others (Contreras, 2016, p. 27).

\section{Gamification Cases in Educational Environments}

Among the most representative characteristics are: the flexibility of the rules of the game; ludic learning with levels of difficulty; the game based on challenges as a factor that motivates the player; the flows and levels of the game; the customization of the game, the scenarios, and characters of the game; the function of co-creation of the game to generate personalized modifications on the part of the player; the scenarios of management of errors and failures, and the instructional design applied to the gamification, among others. 
On the other hand, García (2016) affirms that there is a series of pedagogical principles valid for face-to-face and distance education, which must be taken into account when working with digital content: "individualization, socialization, activity, autonomy, intuition, creativity, and game" (2016, p. 9).

The research carried out by Galbis-Córdova, Martí-Parreño, and Curras-Pérez (2017) determined to explore what were the key factors in terms of the emotional attitude of students when faced with new knowledge in a gamified form, 128 students participated in this research and the ARCS instructional motivation model (Instructional design approach that focuses on motivational aspects of the learning environment. Model was created by John Keller in 1980). It is model that was implemented by Fazamin, Haji Ali, Saman, Yusoff, and Yacob (2015) to evaluate the influence of gamification on student motivation. The most significant contributions of these researchs were to analyze and demonstrate how gamification motivates learning in people, this being a valuable reason to integrate play as a learning strategy in education today.

These researchs provide positive evidences that demonstrated: that the use of gamification contributes to improve the behavior of students when they work with electronic learning platforms, which generates confidence in the use of educational games. Based on the previous model the realization of an analysis of adequate techniques for education and e-learning is the key point of the implementation of gamification. In this study unlike (Galbis-Córdova, Martí-Parreño, \& Curras-Pérez, 2017; Fazamin et al., 2015), it is implemented the GED design model (Design strategy management methodological framework), whose name comes from the combination of gamification and e-learning, demonstrating that through this model you can contribute to the participation and motivation of the students, improving the learning process.

Given that some of the online courses offered today are developed under the e-learning platform, if the student does not show the intention to do it, they can generate a state of loneliness and boredom in the virtual classroom. To control this state by which the student can pass, the investigations of Olsson, Mozelius, and Collin (2015); Auvinen, Hakulinen, and Malmi (2015) propose within their research to use achievement badges as a reward for the development of certain activity, in addition to this implemented progress bars or heat maps, in which it is possible to visualize the level of participation of the student, and thus motivate him to improve his participation in the activity, in the desire to be highly competitive and always want to be the winner. The research concluded that by means of this gamification technique, the motivating effect produced by watching the frequent positive behaviour of the students can be appreciated. 
The works of Rodríguez (2015), Moreira and González (2015) and Rughiniş (2013) have contributed to the improvement of learning processes, especially in the dynamization and interaction with learning of some functions of the human body and helping to better understand the complexity of the vocabulary handled in the area of health according to the authors (Rojas, Cowan, Kapralos, \& Dubrowski, 2014). In contrast to the above, the research of Moreira and González (2015) demonstrated the importance of human-machine interaction in the learning process, and the need for productivity of books and educational materials in digital formats to be accessible to all types of people as proposed (Mageswaran, Zaleha and Hasnah, 2016).

Within the academic scenario, it is worth highlighting the case of the secondary school of the South Malaysian state of Johor in Malaysia, where gamification was applied as a metric for the teaching of sciences; the study was applied to 29 secondary students, through a mixed research design, and making use of the Zondle gamification platform, this platform was used given its dynamic characteristics to be used in children under 13 years of age.

On the other hand, at the University of John Moores, in Liverpool, they implemented gamification not just as an educational learning strategy, but as an application so that people who want to know the institution can do it through virtual reality interacting with each other with the application and the real world, that is, as if the player were immersed in the game, in this way, the main objective of this study is for the population to know the facilities available to the university, and simulate a day within it, this has generated great acceptance in the players, to the point that they make the decision to study at this campus (Curtis, Stephen, \& David, 2015).

The State University of Londrina in Brazil, developed a project called SIGMA, this study emerged seeing the need to implement a strategy that contributes to the learning of secondary school students in complex subjects such as mathematics, arithmetic, and logic algorithms.

Within the research carried out by Toda, Do Carmo, and Silva (2014), the authors concluded that the main objective of the research was achieved, which aimed to unify the system, teacher-student-gamification, and although this project is still in the preparation phase, it is expected that students improve their ability in understanding and mastering the topics.

As suggested by García (2016), a group of researchers in Barcelona, Spain, developed a digital game, with the aim of orienting the educational competencies to elementary school students, implementing in their development the process of cocreation, calling it a game Ferran Alsina, focusing mainly on basic skills and specific methodologies, advising that the game is especially designed for children between 4 and 10 years old (Contreras-Espinosa, Eguia-Gómez, \& Albajes, 2016). 
The work of Evaristo, Vega, Navarro, and Nakano (2016), in Lima, Peru, which involved 561 students, divided into three groups, whose main objective was the identification of the influence of video games in real time, for the development of this project three groups were formed in which the first group worked on the theme only using video games, the second group only theoretical classes, and the third group a hybrid strategy between groups one and two, the results were quite strong, demonstrating that the students of group one, who worked only with video games, had a greater effect on the grades than the other groups. Demonstrating that video games can be used as a pedagogical tool in teaching.

At the National University of Colombia, Cadavid and Gómez (2015), establish the majority of educational institutions in Colombia present a low level of knowledge especially for the area of Mathematics, proposed to design a gamification didactic strategy in order that by through this technique, the students reached the comprehension and mastery of the subject in a more friendly way, this research was done to 2,263 students of the institution in a precalculus course, giving result to an increase in the academic performance with a percentage of acceptable approval and evidencing a lower level of desertion.

Likewise, Butler and Ahmed (2016) also exposes the level of student desertion, especially in the area of computer science, describing that this problem occurs due to lack of motivation or interest in this field. For this research, a game was implemented in which the computer systems were conceptualized in a didactic and fun way: volunteers responded to a survey and compared his acceptance of learning by playing with traditional learning in the classroom. The results showed that gamification is key in changing the learning experience for students in the area of computer sciences and helped them achieve their learning objectives.

\section{Gamification Cases in Business Environments}

Business sectors such as tourism have adopted gamification practices and methods in order to show themselves as an innovative concept in tourism marketing (Xu, Buhalis, \& Weber, 2017) in Hong Kong, a cultural exchange website similar to Airbnb was developed, a gamification strategy so that users can obtain a special card called SuperHost, considered a host card, in which through the gamified platform they can have knowledge of the comments registered by the SuperHost, resulting in a trend of most relevant comments and evaluations. (Liang, Schuckertb, Lawb, \& Chen, 2017).

Within the studies of Malegiannaki and Daradoumis (2017); Petrucco and Agostini (2016), the integration of gamification techniques in the educational trend applied to the formation of cultural heritage, relying on technologies such as augmented reality giving way to a method that provides great potential. This research allowed the study 
of 34 cities, especially developed for the Walled City of Veneto to population between children of 7 and 15 years the cultural and historical importance of the city, integrating gamification with augmented reality for mobile devices, in this way, using visually attractive tools, it is possible to improve pedagogical skills, allowing interaction with the system.

In Colombia there are companies that implement gamification as an alternative to call customers and/or train their employees, among them Playvoz, Alliance between the Colombian Association of Contact Centers and BPO, is a platform that works as a social network but internal to each company, in which through gamification, seeks to be more efficient in the processes of selection, induction and training of personnel in the area of Human Talent in this company, the Arcaris Company, was founded by Oscar Giraldo to identify the achievements that each worker has both at aroup and individual level and rewards depending on what has been achieved (Corporación Colombia Digital [CCD], 2013).

Therefore the research developed by Gómez, Calvo-Manzano, Gasca-Hurtado, and San Feliu (2014) proposes a teaching instrument in which it uses the basic principles of gamification, in order to get software developers to work in a different environment, and in turn obtain more successful projects and processes. Molina (2013), in a way that also advises in his research Ferrández (2013), considers that gamification and marketing strategies contribute to the decision-making process in the company, this being one of the main characteristics to take into account.

The research developed by Sousa-Vieira, López-Ardao, Fernández-Veiga, Rodríguez-Pérez, \& Herrería-Alonso (2016) affirms that these digital natives possess learning skills developed within an online social context, given that online social networks (OSN) are considered an important factor to enter a new dimension of social systems learning management, there are still traditional learning practices avoiding the user experience in a socially active environment. The work of De-Marcos, GarcíaLópez, and García-Cabot (2016) exalt the value that social networks and gamification has had in contributing to education by applying it throughout the educational semester, implementing methods of correlation, component analysis, and multiple regression.

The use of social networks has not only been adopted for roles as students. The study of De-Marcos et al. (2016) describes that this tendency is increasingly coined by teachers and educational institutions giving way to a new trend called social Gamification, in which the main objective is to take advantage of the educational game and social networks as a methodology for the purpose to improve the relationship institution-teacher-student.

In general terms, it is possible to affirm that social networks have contributed to education by demonstrating the effectiveness of e-learning, the research developed 
by De-Marcos, Domínguez, Saenz-de-Navarrete, and Pagés (2014) presents results product test obtained between social networks and gamification for a specific course, in order to compare academic performance, participation, and attitude of students towards this new technology. Resulting in the optimization of both approaches in terms of improving a traditional teaching process, encouraged by electronic learning, affirming that this is a way in which students called digital natives, resemble technologies developed in new approaches, giving positive result to any practice.

\section{Conclusion and Discussion}

The documentary review made it possible to identify the level of research in which the object of study of this work is found; in this case, the concept of gamification was deepened and, at the same time, the potential implementation scenarios were analyzed and discussed.

The gamification is considered a fundamental part of the learning process, it allows you to adapt platforms and use tools in any area of knowledge. Thus managing to incorporate elements of the game in a learning context, and making it improve the motivation to learn as well as the results of the training process.

The implementation of gamification strategies allows generating an innovative educational environment, which contributes to the development of active learning and promotes greater interaction among the participants. The integration of gaming platforms in education or training streamlines training processes and motivates learning.

Once the current state of gamification theory has been explored and analyzed, and after the scientific synthesis supported in this article, it is proposed to evaluate the most technically adequate platforms and tools for the development of a gamified module oriented to secondary education. As a representative sample the module will be applied to students of Grade 11 in the subject of chemistry. It is then proposed as a next step to the investigation to determine the appropriate model to be applied in real scenarios. 


\section{References}

Auvinen, T., Hakulinen, L., \& Malmi, L. (2015). Increasing students' awareness of their behavior in online learning environments with visualizations and achievement badges. IEEE Transactions on Learning Technologies, 8(3), 261-273. https://doi. ieeecomputersociety.org/10.1109/TLT.2015.2441718

Benito, M. (2014, April 27). Gamificación o cómo lograr que los empleados hagan un trabajo extra gratis [Gamification or how to get employees to do an extra job for free]. El Confidencial. Retrieved from http://www.elconfidencial.com/ empresas/2014-04-27/gamificacion-o-como-lograr-que-los-empleados-haganun-trabajo-extra-gratis_121168/

Bonillaware. (2012, May 9). 7 plataformas de gamificación [7 gamification platforms]. Retrieved from http://www.bonillaware.com/7-plataformas-de-gamificacion.

Butler, S., \& Ahmed, D. (2016). Gamification to engage and motivate students to achieve computer science learning goals. 2016 International Conference on Computational Science and Computational Intelligence (CSCI), 237-240. https://doi.org/10.1109/ CSCI.2016.0053

Cadavid, J., \& Gomez, L. F. (2015). Uso de un entorno virtual de aprendizaje ludificado como estrategia didactica en un curso de pre-calculo: estudio de caso en la Universidad Nacional de Colombia [Use of a gamified virtual learning environment as didactic strategy in a pre-calculus course: Case study in the National University of Colombia]. Revista Iberica de Sistemas e Tecnologias de Informação, (16), 1-17. http://dx.doi.org/10.17013/risti.16.1-16

Contreras, R. S. (2016). Juegos digitales y gamificación aplicados en el ámbito de la educación [Digital games and gamification applied to education]. RIED - Revista Iberoamericana de Educación a Distancia, 19(2), 27-33. https://doi.org/10.5944/ ried.19.2.16143

Contreras-Espinosa, R., Eguia-Gómez, J. L., \& Solano-Albajes, L. (2016). Investigaciónacción como metodología para el diseño de un serious game [Action research as a game design methodology for a serious game]. Revista Iberoamericana de Educación a Distancia, 19(2), 71-90. https://doi.org/10.5944/ried.19.2.15624

Corporación Colombia Digital. (2013). Call centers colombianos serán meritocráticos [Colombian call centers will be meritocratic]. Retrieved from http:// colombiadigital.net/actualidad/noticias/item/5321-call-centers-colombianosseran-meritocraticos.html 
Curtis, M., Stephen T., \& David, L. (2015). VICTour 1.1: Introducing virtual learning environments and gamification. 2015 International Conference on Developments of E-Systems Engineering (DeSE). https://doi.org/10.1109/DeSE.2015.66

De-Marcos, L., Domínguez, A., Saenz-de-Navarrete, J., Pagés, C. (2014). An empirical study comparing gamification and social networking on e-learning. Computers \& Education, 75, 82-91. https://doi.org/10.1016/j.compedu.2014.01.012

De-Marcos, L., García-López, E., \& García-Cabot, A. (2016). On the effectiveness of game-like and social approaches in learning: Comparing educational gaming, gamification \& social networking. Computers \& Education, 95, 99-113. https://doi. org/10.1016/j.compedu.2015.12.008

De-Marcos, L., García-López, E., García-Cabot, A., Medina-Merodio, J. A., Domínguez, A., Martínez-Herráiz, J. J., \& Diez-Folledo, T. (2016). Social network analysis of a gamified e-learning course: Small-world phenomenon and network metrics as predictors of academic performance. Computers in Human Behavior, 60, 312-321. https://doi.org/10.1016/j.chb.2016.02.052

Evaristo, I, Vega, M., Navarro, R., \& Nakano, T. (2016). Uso de un videojuego educativo como herramienta para aprender historia del Perú [The use of a video game as an educational tool to learn the history of Peru]. RIED - Revista Iberoamericana de Educación a Distancia, 19(2), 35-52. https://doi.org/10.5944/ried.19.2.15569

Fazamin, A., Haji Ali, N., Saman, Y., Yusoff, M., \& Yacob, A. (2015). Influence of gamification on students' motivation in using e-learning applications based on the motivational design model. International Journal of Emerging Technologies in Learning, 2015, 10(2), 30-34. http://dx.doi.org/10.3991/ijet.v10i2.4355

Ferrández, M. (2013). El “jidoka” y la gamificación al servicio del control de gestión [The "jidoka" and gamification to support management control]. Estrategia Financiera, (306), 58-63.

Galbis-Córdova, A., Martí-Parreño, J., \& Curras-Perez, R. (2017). Higher education students' attitude towards the use of gamification for competencies development. Journal of e-Learning and Knowledge Society, 13(1), 129-146. Retrieved from https://bit.ly/2S9BFHY

García, A. L. (2016). El juego y otros principios pedagógicos. Supervivencia en la educación a distancia y virtual [Games and other pedagogical principles: Its continued existence in distance and virtual education]. RIED - Revista Iberoamericana de Educación a Distancia, 19(2), 9-23. https://doi.org/10.5944/ ried.19.2.16175 
Gómez, M. C., Calvo-Manzano, J. A., Gasca-Hurtado, G., \& San Feliu, T. (2014). Design of a pedagogic instrument for teaching software process improvement: Teaching instrument for university and business environments. 2014 9th Iberian Conference on Information Systems and Technologies (CISTI). IEEE, 1-7. https://doi. org/10.1109/CISTI.2014.6876873

Hamari, J., \& Keronen, L. (2017). Why do people play games? A meta-analysis. International Journal of Information Management, 37(3), 125-141. https://oi. org/10.1016/j.ijinfomgt.2017.01.006

Hamari, J., Koivisto, J. A., \& Sarsa, H. (2014). Does gamification work? A literature review of empirical studies on gamification. 47th Hawaii International Conference on System Sciences (HICSS), 3025-3034. https://doi.org/10.1109/HICSS.2014.377

Hanus, M. D., \& Fox, J. (2015). Assessing the effects of gamification in the classroom: A longitudinal study on intrinsic motivation, social comparison, satisfaction, effort, and academic performance. Computers \& Education, 80, 152-161. https:// doi.org/10.1016/j.compedu.2014.08.019

Liang, S., Schuckertb, M., Lawb, R., \& Chen, C. (2017). Be a "Superhost": The importance of badge systems for peer-to-peer rental accommodations. Tourism Management, 60, 454-465. https://doi.org/10.1016/j.tourman.2017.01.007

Mageswaran, S., Zaleha, A., \& Hasnah, M. (2016). The affiliation between student achievement and elements of gamification in learning science. 4th International Conference on Information and Communication Technology (ICoICT). https://doi. org/10.1109/ICoICT.2016.7571962

Malas, R., \& Hamtini, T. (2016). A gamified e-learning design model to promote and improve learning. International Review on Computers and Software (IRECOS), 11(1), 8-19. https://doi.org/10.15866/irecos.v11i1.7913game

Malegiannaki, I. \& Daradoumis, T. (2017). Analyzing the educational design, use and effect of spatial games for cultural heritage: A literature review. Computers \& Education, 108, 1-10. https://doi.org/10.1016/j.compedu.2017.01.007

Mattar, J. \& Nesteriuk, S. (2016). Estratégias do design de games que podem ser incorporadas à educação a distancia [Game design strategies that can be adopted in distance education]. Revista Iberoamericana de Educación a Distancia, 19(2), 91-106. https://doi.org/10.5944/ried.19.2.15680

Molina, J. C. (2013). A jugar con los clientes: gamificación y marketing. MK: Marketing + ventas, (286), 8-15. 
Moreira, M. \& González, C. S. (2015). De la enseñanza con libros de texto al aprendizaje en espacios online gamificados [From teaching with textbooks to learning on online gamified spaces]. Educatio Siglo XXI, 33(3), 15-38. https://doi. org/10.6018/j/240791

Olsson, M., Mozelius, P., \& Collin, J. (2015). Visualisation and gamification of e-learning and programming education. Electronic Journal of e-Learning, 13(6), 441-454. Retrieved from http://www.ejel.org/issue/download.html?idArticle=477

Petrucco, C., \& Agostini, D. (2016). Teaching cultural heritage using mobile augmented reality. Journal of e-Learning and Knowledge Society, 12(3), 115-128. Retrieved from https://www.learntechlib.org/p/173477/

Rojas, D., Cowan, B., Kapralos, B., \& Dubrowski, A. (2014). Gamification and health professions education. 2014 IEEE Games Media Entertainment, 1-2. https://doi. org/10.1109/GEM.2014.7048114

Roosta, F., Taghiyareh, F., \& Mosharraf, M. (2016). Personalization of gamificationelements in an e-learning environment based on learners' motivation. 2016 8th International Symposium on Telecommunications (IST), 637-642. https://doi. org/10.1109/ISTEL.2016.7881899

Rughiniş, R. (2013). Gamification for productive interaction: Reading and working with the gamification debate in education. Paper presented at the 8th Iberian Conference on Information Systems and Technologies (CISTI), Lisboa, Portugal. Retrieved from https://ieeexplore.ieee.org/document/6615731

Seaone, I. (2016). Herramientas para empezar a gamificar [Tools to start to gamify]. Retrieved from http://entreparentesis.org/herramientas-empezar-gamificar/

Sousa-Vieira, M. E., López-Ardao, J. C., Fernández-Veiga, M., Rodríguez-Pérez, M., \& Herrería-Alonso, S. (2016). An open-source platform for using gamification and social learning methodologies in engineering education: Design and experience. Computer Applications in Engineering Education, 24(5), 813-826. https://doi. org/10.1002/cae. 21746

Toda, A., Do Carmo, R., Silva, A., \& Brancher J. (2014). Project SIGMA - An online tool to aid students in math lessons with gamification concepts. 33rd International Conference of the Chilean Computer Science Society (SCCC). https://doi.org/10.1109/ SCCC.2014.35 
Viera-Rodríguez, K., Pardo, J., Ben-Abdellah, L., Martín, S., Ávila-Detomás, J. (2015). Gamificación: papel del juego en las aplicaciones digitales en salud [Gamification: the role of gaming in digital health applications]. FMC - Formación Médica Continuada en Atención Primaria, 22(7), 369-374. http://dx.doi.org/10.1016/j. fmc.2015.05.002

$\mathrm{Xu}, \mathrm{F}$, Buhalis, D., \& Weber, J. (2017). Serious games and the gamification of tourism. Tourism Management, 60, 244-256. https://doi.org/10.1016/j.tourman.2016.11.020

\section{Authors}

* Zulma Liliana Vargas-Macías. Professor and researcher at Universidad Pedagógica y Tecnológica de Colombia. She holds a Master's in computer technology and Systems and Computing Engineering Tunja, Colombia. Reasearch group TelemaTICs and TICA.

ORCID: https://orcid.org/0000-0001-7766-3556

Ariel Adolfo Rodríguez-Hernandez. Professor and researcher at Universidad Pedagógica y Tecnológica de Colombia. He holds a Master's in Free Software. Also, he is an expert in Training and Virtual Tutoring, is a Systems Engineer with an emphasis in software. Reasearch group TelemaTICs and TICA.

ORCID: https://orcid.org/0000-0003-1906-7734

Claudia Liliana Sánchez-Sáenz. Professor and researcher at Universidad Pedagógica y Tecnológica de Colombia. She holds a $\mathrm{PhD}$ in Education, a Master's in Educational Technology and a BA in Educational Technology. Reasearch group TelemaTICs and TICA

ORCID: https://orcid.org/0000-0002-2952-0857

How to reference this article: Vargas-Macías, Z. L., Rodriguez-Hernandez, A. A., \& SanchezSaenz, C. L. (2020). Digital games (Gamification) in Learning and Training: an Approach to Adaptation and Integration in the Classroom. GIST - Education and Learning Research Journal, 20, 171-188. https://doi.org/10.26817/16925777.765 